\title{
UN MEETING POINT DE LOS ORDENAMIENTOS JURÍDICOS SOBRE CONTRATACIÓN PÚBLICA
}

\author{
JosÉ LUIS MEILÁN GIL ${ }^{1}$ \\ Catedrático de Derecho Administrativo \\ Universidad de A Coruña
}

\begin{abstract}
RESUMEN
Procesos de integración supranacional como el de la UE y, en definitiva, la globalización reclaman por razones prácticas un encuentro de las diferentes regulaciones de los contratos públicos existentes. Desde un punto de vista doctrinal se propone como solución la idea del contrato como un oberbegriff que comprende a los contratos civiles y públicos, en igualdad de condiciones. El interés general que el poder contratante ha de procurar está ínsito en el objeto del contrato. Los derechos y obligaciones nacen del contrato, no de poderes fuera de él como sucede en el contrato administrativo franco-español. Por ello adquiere especial importancia la preparación y adjudicación o formalización del contrato. No es necesario acudir a prerrogativas de la Administración y no será obstáculo para ese encuentro el diferente sistema de revisión judicial del conmon law o el del régime administratif y jurisdicción contencioso-administrativa.

Palabras clave: contrato administrativo; contratos públicos; Directivas de la Unión Europea; contract clause; globalización; interés público; privilegios; revisión judicial.
\end{abstract}

\begin{abstract}
Supranational integration process and the globalization call for a practical meeting point of the national regulations of public contracts. From a theoretical point of view the idea of contract as an obergriff, private and public contracts contents, may be a solution. The general interest that contracting power must promote is inherent to the contract object. Rights and obligations from the contract proceed, and no from outsiders privileges. For that, is very important the preparation an adjudication of the public contracts. The different systems for judicial review are not a big problem.
\end{abstract}

Key words: administrative contract; public contracts; procurement; UE Directives; contract clause; globalization; public interest; privileges; judicial review.

1 Texto ampliado de una intervención en el Congreso Internacional de Derecho Administrativo, Puerto Rico, 2015.

Revista de Administración Pública

ISSN-L: 0034-7639, núm. 198, Madrid, septiembre-diciembre (2015), págs. 43-73 http://dx.doi.org/10.18042/cepc/rap.198.02 


\section{SUMARIO}

I. Planteamiento.--II. El itinerario de la investigación: 1. Acto y contrato.III. AlteRnativas DE LOS ORDENAMIENTOS JURÍDicos: 1. La configuración del contrato administrativo: el paradigma francés. 2. La orientación alemana. 3. El Common Law.-IV. RECONSTRUCCIÓN DE LA CATEGORÍA CONTRACTUAL.-V. El TEST DEL DERECHO DE LA UNIÓN EUROPEA.-VI. A LA BÚSQUEDa DE UN MEETING POINT EN LA CONTRATACIÓN PÚBLICA.-VII. LA CONTRATACIÓN PÚBLICA COMO ESTRATEGIA POLÍTICA.

\section{Planteamiento}

Es un dato no controvertido que, a lo largo del tiempo, de una u otra forma, con un régimen jurídico público o privado, con sometimiento a una jurisdicción específica o a la jurisdicción común competente para el examen de las controversias que surjan, el Poder en diferentes manifestaciones a lo largo de la historia ha utilizado la técnica contractual para atender a necesidades que se identificaban con el interés de la Corona, del bien común o del interés general o public interest. La deferencia por el contrato se manifiesta en el nivel constitucional (EE.UU.), tradicionalmente en el de la legislación de los Estados como España $^{2}$, y en la UE, donde la actividad directa, las llamada operaciones in house providing, es excepcional ${ }^{3}$.

Como sucede con otras categorías jurídicas, las diferencias provienen de la trayectoria seguida por cada país, de la concepción del Estado y, en particular, de sus relaciones con la sociedad, de lo que dan testimonio los sistemas constitucionales. En el tema contractual puede constatarse una retroalimentación de doctrina con jurisprudencia y legislación de lo que es paradigmático el caso francés y, en su órbita, el español y muchos latinoamericanos.

La importancia de estos contratos, en términos económicos, es creciente por la imparable globalización. La diversidad de los ordenamientos jurídicos es una dificultad y también un reto. Para empezar, ni siquiera existe unanimidad en el nombre. Los contratos administrativos «a la francesa» han sido ignorados en Alemania, que siguió una peculiar vía privatista. Ahora, en la Unión Europea se habla de contratos públicos en sus Directivas que no abarcan todos los contratos de los Po-

2 Cfr. J. L. Meilán GIL, «Las prerrogativas de la Administación en los contratos administrativos: propuesta de revisión», $R A P, 191,2013$, págs. 24-26.

3 Cfr. J. L. MeIlán GiL, La estructura de los contratos públicos, Iustel, Madrid, 2006, págs. 114 y ss.; J. J. PERnAS, Las operaciones in house y el Derecho comunitario de contratos públicos, Iustel, Madrid, 2008, con Prólogo de J. L. MEILÁN GIL. 
deres públicos y que no se refieren solo a contratos de las Administraciones públicas. De otra parte, los öffentlicherechtlichen Verträge no coinciden con esos contratos públicos. En la Alemania actual los contratos públicos lo son, podría decirse en cuanto a la preparación y adjudicación del contrato. Solo en relación con ello puede hablarse de un carácter público de esos concretos contratos en el Reino Unido y, por supuesto, esos contratos son privados en EE.UU., amparados en una clásula constitucional expresamente prevista desde la óptica civil, bajo la misma jurisdicción como tradicionalmente ha sucedido en el RU y se ha acogido también en algún país latinoamericano.

Cómo puede llegarse a un operativo meeting point en esta Babel. En alguna ocasión he hablado de la necesidad de desacralizar expresiones como dogmática o doctrina. Y, sin embargo, es necesario contar con referencias que den sentido, proporcionen y exijan coherencia a las cada vez más extensas y complejas regulaciones jurídicas que nos desbordan. Son necesarias categorías jurídicas ${ }^{4}$, de lo que me he preocupado en publicaciones desde el comienzo de mi vida universitaria, aprendiendo de maestros a revisarlas a partir de ellos. Del profesor VilLaR PaLASí aprendí, sobre todo, un método. Quizá eso es lo más valioso que puede dejarse a los discípulos, con libertad para sacar las propias conclusiones, sin tener que estar sometido a la disciplina de una auctoritas jerárquica.

En la búsqueda necesaria de las categorías jurídicas adecuadas existen riesgos que habrán de evitarse. Sin orden de importancia podría sentarse un axioma: no pedir a la categoría más de lo que ella puede dar; no estirarla tanto que deje de cumplir con su misión de certeza y claridad. Hay que someterlas a una prueba de fuego, como se hace con los materiales, para verificar si son «de ley», que no son aleaciones, que no tienen adherencias que las desvirtúen. Habrá que desmontar sus piezas para comprobarlo. Cuál ha sido el proceso que ha servido para construirlas. No quedarse en la literalidad: servicio público no tiene el mismo significado en todos los ordenamientos y en su sentido más estricto no se identifica con las public utilities.

Hasta qué punto las categorías jurídicas son deudoras de circunstancias políticas, tan propias del Derecho administrativo - «su servidumbre respecto de la oportunidad, su apego a la política», dejé escrito en $1967-5$ y, en último término, del concepto del Estado en que se construyeron. La circunstancia no es decisiva para dar una respuesta, 2011

4 Cfr. J. L. MeIlán GIL, Categorías jurídicas en el Derecho administrativo, Iustel, Madrid,

5 Cfr. El proceso de la definición del Derecho administrativo, ENAP, Madrid, 1967.

Revista de Administración Pública

ISSN-L: 0034-7639, núm. 198, Madrid, septiembre-diciembre (2015), págs. 43-73

http://dx.doi.org/10.18042/cepc/rap.198.02 
que debe completarse con la comprobación de su auténtica y no meramente formal supervivencia. En todo caso, es preciso rastrear el origen de la categoría y comprobar hasta qué punto ha sido erigida en un dogma jurídico inamovible; si se encuentra condicionada por el modo de prever la revisión judicial. Es también necesario constatar si la categoría jurídica tiene un alcance suficientemente generalizado, lo que será cada vez más relevante habida cuenta de la tendencia hacia integraciones supraestatales y el proceso de globalización ${ }^{6}$.

\section{EL ITINERARIO DE LA INVESTIGACIÓN}

\section{Acto y contrato}

1.1. Al tema contractual me he dedicado desde los comienzos de mi andadura académica. En 1968 fue objeto de la denominada «lección magistral» en el concurso con el que gané la plaza de Catedrático de Derecho administrativo de la Universidad de Santiago de Compostela. Había mucho escrito entonces en España sobre la categoría del contrato administrativo con declarada influencia de la orientación francesa, que sigue dominando también en gran parte de Latinoamérica. La cuestión central del planteamiento teórico consistía en relacionarlo con el contrato civil, modulado por la presencia de la Administración. En esa modulación consistía la denominada exorbitancia de sus cláusulas respecto del contrato entre particulares, manifestada en la existencia de privilegios o prerrogativas de la Administración. Son respuestas que se dan desde la doctrina iusadministrativista a planteamientos civilistas. ¿Cómo puede haber contratos si las partes - una de ellas titular del poder - no están en situaciones de igualdad? ¿Cómo puede quedar la Administración o el Príncipe ligados por la lex contractus? Mi punto de vista fue diferente, de acuerdo con mi propia concepción del Derecho administrativo y, en último término, de su construcción.

Era preciso comprobar cómo se había abordado la cuestión en los distintos ordenamientos jurídicos, expresión de tradiciones no coincidentes, e inquirir cuáles son sus causas y sus justificaciones. Separándome de la aproximación dominante franco-española y partiendo de la condición reconocida del Derecho administrativo como ius commu$n e^{7}$, puse el acento en sus peculiaridades percibidas en la realidad: exis-

${ }^{6}$ Cfr. J. L. MeILÁn GIL, Una aproximación al Derecho administrativo global, Ed. Global Law, Sevilla, 2011.

7 J. L. MeILÁn GiL, El proceso de la definición... 
tencia de normas con rango inferior a la ley y su aplicación. Lo normal en este ámbito es que la creación de derechos y obligaciones sea el resultado de un desarrollo y una concreción de la norma, mediante actos unilaterales con los que el poder se impone al particular, o mediante contratos en los que el poder se vincula con la voluntad del particular. La utilización de una u otra opción no está absolutamente predeterminada. En todo caso, acto y contrato implican ejecución de una norma, expresado en términos de dogmática jurídica con influencia alemana ${ }^{8}$.

Las consecuencias diferentes de actuar por imposición o por contrato se comprueban mucho antes de que se hubiese construido una teoría del contrato administrativo ${ }^{9}$ y también en ordenamientos jurídicos contemporáneos, reconozcan o no la del acto administrativo ${ }^{10}$. Por eso, en lugar de contraponer contrato administrativo y contrato civil, me propuse subrayar la bipolaridad acto-contrato, ya que la actuación de la Administración mediante actos unilaterales y contratos es un punto de partida propio del Derecho administrativo ${ }^{11}$ y no del Derecho civil, en donde son raras las potestades, si quedan todavía, y donde hay un rechazo a la imposición unilateral. Fue el meollo de aquella lección ${ }^{12}$, que siguió a un trabajo anterior sobre la diferencia entre la norma y el acto administrativo ${ }^{13}$.

Esta aproximación teórica se confirma en la práctica observable en todos los países, con mayor o menor preferencia, incluidos los del

8 Cfr. J. MARTENS, «Normenvollzug durch Verwaltungsakt und Verwaltungsvertrag», Archiv des offentlichen Recht, 89, 1964.

9 Toda la larga historia de los pleitos colombinos, que duran más de siglo y medio, tiene por fondo este mismo planteamiento: el Rey ha concedido una merced y puede ser revocada o, por el contrario, se alega que las capitulaciones tienen alma y cuerpo de contrato. En Speculum Principium, Bruselas, 1654, P. BELluga expone que el Príncipe podía actuar por modum privilegii —otorgando rescriptos- o por modum contractus, pero en este caso los derechos nacidos de lo pactado irrevocabilia fiunt.

10 En EE.UU. la cuestión se plantea como consecuencia de la interpretación rígida de la contract clause en los casos Fletcher v. Peck, en 1810, y Darmouth College v. Woordad, en 1919. Sobre la posibilidad de «legislar» con efectos retroactivos o modidificar el contrato, el leading case de la interpretación es Home Building y Loan Ass. v. Blaisdell, 290 U.S. (1934).

11 Cfr. J. L. Villar Palasí y J. L. Villar Ezcurra, Principios de Derecho administrativo, T. III: Contratación administrativa, Universidad de Madrid, 1983, págs. 20-22. La dialéctica es muy significativa en la doctrina alemana por la influencia de Otto MAYER, Derecho administrativo alemán, T. I, Buenos Aires, págs. 125 y ss.; M. Bullinger, Vertrag und Verwaltungsakt, Stuttgart, 1962.

12 La actuación administrativa por vía del acto y del contrato, inédita, que se ha integrado y desarrollado en posteriores trabajos. Ampliamente en J. L. MEILÁN GIL, La estructura de los contratos públicos, Iustel, Madrid, 2008.

13 La distinción entre norma y acto administrativo, ENAP, Madrid, 1967, con referencia a obras entonces recientemente publicadas: D. VolKMAR, Allgemeiner Rechtssatz und Eizenlakt, Versuch einer begrifflichen Abgrenzung, Berlín, 1962; G. SANTANELLO, Gli atti amministrativi a contenuto non normativo, Milán, 1966; J. M. RaInAud, La distinction de l'acte réglementaire et de l'acte individuel, París, 1966. 
Common Law $^{14}$. En EE.UU., donde no existe la categoría continental del acto administrativo ${ }^{15}$, la primacía del contrato está respaldada constitucionalmente. Los vested right están protegidos por la contract clause al amparo del artículo 1, sec. 10, de la Constitución, según el cual: «No state shall pass any... Law impairing the obligation of Contracts», reforzado por las enmiendas quinta y decimocuarta a la Constitución ${ }^{16}$. Desde esta perspectiva puede observarse en la jurisprudencia americana la dualidad antes referida. Las consecuencias de la calificación o no de contrato, sometido a la cláusula constitucional, estarán presentes a la hora de decidir. En el bien entendido que, como muy temprano fue reconocido, la obligación que se menciona en la citada cláusula es de origen y naturaleza civil, incorporada al contrato y formando parte de é ${ }^{17}$. Ha de tenerse en cuenta, además, que la terminología no se corresponde exactamente con la europea. Así, los publics contracts realizados por una governmental entity y un particular incluyen charters y licences.

Hitos fundamentales de esa historia son los casos Fletcher v. Peck, en $1810^{18}$, y Darmounth College v. Woodward, en $1819^{19}$. El primero declara que, en aplicación de la contract clause, las concesiones de tierras hechas por el legislativo del Estado de Georgia eran irrevocables. La Constitución no distingue según los contratos, dirá el juez Marshall. Cuando una «ley» es por naturaleza un contrato «absolute rights have vested under contract» y una nueva «ley» no puede desconocer$\operatorname{los}^{20}$. En el segundo caso se define que la corporation charter - estatuto que crea una persona jurídica para la realización de determinados fines públicos, una Universidad - es un contrato. Esto significaba que el Estado se encontraba atado por la contract clause; las condiciones es-

14 Ad exemplum, cfr. S. ARrowsmith, "Government contracts and public law», Legal Studies, vol. 10, núm. 3, 1990, pág. 231. Por lo que se refiere a los EE.UU., cfr. J. L. MeILÁN GiL, La estructura..., págs. 64 y ss., sobre las limitaciones de la contract clause.

15 Makingrule-adjudication americanos no se corresponden exactamente con norma-acto continental europeo, pero tienen funciones equivalentes desde orientaciones constitucionales diferentes.

16 No person shall be... deprived of life, liberty or property without process of law; nor shall private property be taken for public use, without just compensation (de la enmienda $5 .^{a}$ ). Nor shall any State deprive any person of life, liberty or property without due process of law (de la enmienda 14. ${ }^{\mathrm{a}}$ ). MADISON, en The Federalist, se manifestó en contra de "sudden changes and legislative interferences in cases affecting personal rights». Freedom of contract es un derecho inherente al orden natural: laws impairing the obligation of contracts were regarded as contrary the first principle of the social compact.

17 Walker v. Whitehead, 83 U.S. 314 (1873); Word v. Lovett, 313 U.S. 362.370 (1941).

1810 U.S. (6 Cr.) 87.

1917 U.S. (4 Wheat) 518.

20 En el mismo sentido, New Jersey v. Wilson, 11 U.S. (7 Cr. ) 164 (1812), sobre concesión de exención de impuestos sobre tierras. 
tablecidas en la charter deberían ser mantenidas en el futuro; un futuro, además, indeterminado porque, según expresiones del fallo, la corporation es inmortal.

La jurisprudencia ha ido arbitrando diversas fórmulas para limitar el alcance de la aplicación de la contract clause. En ese sentido, una vía es negar el carácter de contrato a concesiones públicas, distinguiendo las grants of privileges que son contratos y las que son licenses revocables. Cabe también el expediente de afirmar que un determinado acuerdo no es un contrato, interpretando la ambigüedad de los términos en que esté suscrito ${ }^{21}$. Un dato a comprobar es si existe una obligación en el recipiendario de una subvención o de la donación de una propiedad de utilizar ésta o los fondos públicos recibidos para un concreto destino $^{22}$. La mayoría de los casos refleja que se trata de acuerdos de carácter contractual ${ }^{23}$. Otra vía ha ido de la mano de la interpretación de las charter corporations con el objeto de reducir a sus estrictos términos el alcance de la contract clause. En el caso Darmounth College v. Woodward, el juez Marshall proporcionó la pista. Se trata de conocer la intención, la voluntad de la Administración: the rule of strict construction. El leading case fue el Charles River Bridge v. Warren Bridge ${ }^{24}$.

En el Reino Unido no existe una cláusula constitucional como en EE.UU., pero la tradición británica es también declaradamente contractualista, en el sentido de someter los contratos de las autoridades públicas al Derecho privado. DicEY es la referencia doctrinal inexcusable $^{25}$. Ha regido el principio, característico de las relaciones entre particulares, expresado en la freedom of contract ${ }^{26}$. También podía observarse una interpretación para negar la condición de contrato, con la consecuencia de la vinculación que ello suponía para la Corona, a una relación jurídica establecida entre el Poder y un particular. El leading case es el Amphitrite v. the King, fallado en $1921^{27}$. Un compromiso aceptado por el cónsul británico en Estocolmo con los propietarios de ese barco, por el cual quedaba libre del bloqueo determinado durante

\footnotetext{
21 Por ejemplo, una concesión de una lotería puede ser revocable por razones morales usando el poder de policía.

22 Por la no calificación de contrato, Alabana v. Shmidt, 232 U.S. 168 (1914); Madison Country Bd. of. Ed. v. Illinois Cent R.R. Co., 939 F. 2d 292 (1962).

23 Thermalon Indus, Ltd v. United States, 34 Fed. Cl. 411 (1955).

2436 U.S. (11 Pet) 420 (1837).

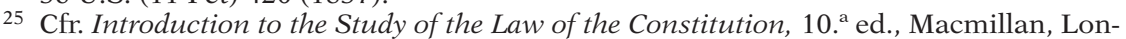
dres, 1959.

26 Cfr. P. CANe, An introduction to administrative law, 3. a ed., Oxford, 1996, págs. 257 y ss.; S. Arrowsmith, "Government Contracts and Public Law», Legal Studies, 10, 1990, págs. 231 y ss.

273 KB 500. Más datos en J. L. MeILÁn GIL, La estructura..., págs. 72 y ss.
} 
la Primera Guerra Mundial si llevaba mercancías al Reino Unido, no fue posteriormente respetado. El juez Rowlat decidió que ese compromiso no era un enforceable contract. La Corona mantenía la libertad propia de una executive action; en definitiva, una acción -llámese acto o privilegio- revocable.

En Francia el acto administrativo se encuentra en el nacimiento y evolución del contrato administrativo ${ }^{28}$. La identificación de acto y contrato se realiza a efectos de un control jurisdiccional específico para preservar de invalidez las ventas de bienes nacionales y consolidar la revolución haciendo propietarios a los partidarios. Va a incidir en la construcción del contrato administrativo. Una afirmación contenida en el arrêt Terrier, de 6 de febrero de 1903, es, en ese sentido, paradigmática: «todo lo que concierne a la organización y funcionamiento de los servicios públicos propiamente dichos, ya actúe la Administración por vía de contrato, ya lo haga por vía de autoridad, constituye una operación administrativa que es, por su naturaleza, del dominio de la jurisdicción administrativa». Junto a los actos de autoridad surgirán los actos de gestión que darán lugar a unos peculiares contratos administrativos.

En Alemania, en cambio, la función y valor que se otorga al acto administrativo va a impedir que allí se reconozca el contrato administrativo. El Rechtstaat, según Otto MAYER, «se perfecciona en virtud del acto administrativo» y el Derecho administrativo moderno "está dominado por él» ${ }^{29}$. El Estado - dirá- manda siempre unilateralmente. Las relaciones jurídico-públicas no pueden ser sino de carácter unilateral, fundadas en la exclusiva voluntad del Estado, constituyendo, por tanto, una imposibilidad lógica la figura del contrato administrativo en cuanto relación jurídico-pública de carácter bilateral, que implicase una situación de igualdad entre el Estado y el particular ${ }^{30}$.

1.2. Una explicación dogmática ${ }^{31}$ puede darse desde la consideración inicial de acto y el contrato como ejecución de la norma. Cuan-

28 Ibid., págs. 76 y ss.

29 Derecho..., cit., pág. 125.

30 Todavía en 1962, Bullinger, Vertrag und Verwaltunstakt, afirmará que es indigno para el Estado pactar con los súbditos, ya que esto supondría escaparse a la responsabilidad y atadura soberana. Como observa F. Sosa WAGner, Maestros alemanes del Derecho público, 2. ${ }^{\mathrm{a}}$ ed., Marcial Pons, Madrid, 2005, pág. 87, «toda la construcción jurídica que caracterizaría al Estado conspiraba en contra de la aceptación de la figura del contrato administrativo».

31 Cfr. J. L. Meilán GiL, «Para una reconstrucción dogmática de los contratos administrativos», Anuario de la Facultad de Derecho de la Universidad de A Coruña, 8, 2005, págs. 505-518. 
do la voluntad del particular es un elemento del supuesto de hecho previsto en la norma estamos ante un contrato. En ese caso, la concreción de la norma exige esencialmente la voluntad del particular. En cambio, cuando el supuesto de hecho está totalmente predeterminado en la norma y lo único que falta es su aplicación individual nos encontramos ante un acto. Esa aplicación es justamente la función del acto. Sucede que, en ocasiones, esa aplicación requiere la aceptación del particular, como destinatario de la concreción de la norma. Seguimos estando ante un acto, con posibles cláusulas accesorias, pero no ante un negocio jurídico de naturaleza contractual. La voluntad del particular opera como simple condición de eficacia.

En otras palabras. El supuesto de hecho que constituye el contenido del acto está predeterminado; la voluntad del particular queda siempre fuera del contenido de ese acto, la voluntad del particular hace posible que la norma se aplique a un caso singular. En los actos necesitados de aceptación la voluntad del particular se yuxtapone al contenido del acto. Por el contrario, la voluntad del particular contribuye a la formación del contenido del contrato, forma parte del supuesto de hecho en que se va a concretar la norma, constituye junto con la «voluntad» de la Administración, expresada en el acto de adjudicación, el núcleo mismo, indivisible, del ente jurídico que llamamos contrato, que deviene ley entre las partes. La voluntad del particular, en este caso, es condición de validez ${ }^{32}$.

1.3. Esa aproximación llevó a poner el acento en la fase de preparación y adjudicación de los contratos realizados por la Administración, en lugar de ponerlo en la ejecución del contrato, como era común y lo sigue siendo en gran medida en la doctrina. En ellos radica la peculiaridad de los contratos realizados por la Administración, incluidos los de carácter privado ${ }^{33}$. No es preciso desintegrar el contrato construyendo la ficción jurídica de unos actes détachables, consecuencia de un revirement del Conseil d'État, que al ampliar la legitimación para recurrir los contratos de la Administración rompe la unidad del contrato. Esa separación ha sido tradicional en el Reino Unido y en Alemania, hasta el punto de que la etapa preparatoria es de carácter interno ajeno a la formalización del contrato. He sostenido, en cambio, que el acuerdo, característico de todo contrato, por el que la Administración y el particular se autovinculan, se lleva a cabo de conformidad con sus

32 En términos próximos me manifesté en la citada lección magistral. Cfr. G. ARIÑo, «El enigma del contrato administrativo», RAP, 172, 2007, pág. 90.

33 Cfr. J. L. MEILÁN GiL, La estructura... 
propios cauces de manifestación. El equivalente a la voluntad del particular es el acto de adjudicación, acto final de un procedimiento ${ }^{34}$.

Esa aproximación es la que, en definitiva, ha adoptado la Unión Europea para garantizar la efectividad de un mercado único en el que operan ordenamientos jurídicos con tradiciones diferentes. En ese sentido, el Derecho comunitario se ha convertido en un meeting point, al que han debido amoldarse Alemania y el Reino Unido, en donde, por distintas razones, el procedimiento de adjudicación del contrato no era accesible a la reclamación judicial por los particulares.

1.4. El último paso dado en la materia es consecuencia de lo anteriormente expuesto. La ejecución del contrato y, de un modo muy significativo, la modificación pueden afectar al principio de igualdad de trato que debe regir el procedimiento que conduce a la adjudicación del contrato, esencial para asegurar el mercado único. Tanta importancia tiene aquél que las irregularidades que se detecten pueden ser recurridas por cualquiera de los participantes ante una autoridad independiente que resuelve en un plazo breve, con suspensión del procedimiento, sin perjuicio de que pueda recurrirse ante la jurisdicción correspondiente. Esta circunstancia me llevó a proponer la eliminación de las prerrogativas de la Administración en los contratos públicos en que interviene ${ }^{35}$, que se manifiestan en la utilización de un acto unilateral con efectos ejecutivos. Ahí quedó ya expedita la etapa final del itinerario académico en coherencia con su inicio que ha conducido a aceptar el contrato como un supraconcepto, Oberbegriff, que incluya en él sin desnaturalizarse los contratos del poder público y los contratos entre los ciudadanos.

Lo que se propone es dar una respuesta jurídica adecuada a esos contratos del Poder, en los que existe un interés general que aquél ha de procurar, inexistente o en todo caso no obligatorio en el contrato entre particulares, y al mismo tiempo que responda a lo que es definitorio de un contrato, en el que las partes se encuentren en igualdad de posiciones. Estas dos cuestiones se han planteado de distinto modo en los diferentes ordenamientos, aunque existen elementos coincidentes.

\footnotetext{
34 Cfr. J. L. MeILÁN GIL, «Una concepción iusadministrativa de los contratos públicos», en Categorías..., págs. 141 y ss.

35 Cfr. J. L. MEILÁN GIL, «Las prerrogativas de la Administración en los contratos administrativos», RAP, 191, 2013.
} 


\section{Alternativas DE lOS ORDENAMIENTOS JURÍDicos}

\section{La configuración del contrato administrativo: el paradigma francés}

La literatura jurídica sobre el contrato administrativo como categoría jurídica y sus diferentes modalidades es innumerable. Reconocido en ordenamientos jurídicos (Francia, España, Latinoamérica), ha sido ignorado como tal en otros (RU, EE.UU.); se ha cuestionado su posibilidad por la desigualdad de posiciones de las partes, impropia de un contrato (Alemania); ha sido objeto de polémicas doctrinales (Argentina, España); se ha negado su naturaleza específica al considerarlo un contrato civil modulado por la presencia de la Administración pública y justificado por estar sometido a un singular control jurisdiccional de la actividad de la Administración, el contencioso-administrativo, con diferentes versiones que no es del caso examinar.

Desde el punto de vista de esa construcción doctrinal interesa subrayar que la afirmada modulación del contrato civil, que durante mucho tiempo se ha considerado como el único, se produce, según una sólida doctrina, por «la presencia subjetiva de la Administración sobre la abstracta institución contractual» ${ }^{36} \mathrm{y}$, en consecuencia, por las peculiaridades de la Administración como organización pública y de su giro peculiar y propio ${ }^{37}$. Esto último se manifiesta sobre todo en las reglas de ejecución, cumplimiento y extinción de los contratos; son las «cláusulas exorbitantes», las «prerrogativas del poder público».

La más genuina de ellas, "por excelencia» se dice, es «el privilegio de la decisión unilateral y ejecutoria, previa al conocimiento judicial, que impone al contratista el deber de su cumplimiento inmediato con la carga de la impugnación contencioso-administrativa si está disconforme con su legalidad ${ }^{38}$. Esa prerrogativa viene a ser la clave de bóveda de la teoría, en lo que se insiste: «este formidable poder no resulta propiamente del contrato mismo», sino del citado privilegio general de autotutela. Eso servirá de explicación para las alteraciones del contrato, el conocido privilegio o prerrogativa del ius o potestas variandi, «la regla exorbitante por excelencia en la contratación administrativa... que permitiría a la Administración modificar unilateralmente el contrato» ${ }^{39}$.

36 Cfr. E. García de EnTERría, Curso de Derecho administrativo, 6. ${ }^{a}$ ed., Civitas, Madrid, 1993, pág. 660 .

37 Ibid., pág. 661.

38 Ibid., pág. 663.

39 Ibid., pág. 664. 
Cuando se invocan, sigue diciéndose, se trata «de la aparición de potestades administrativas que se mueven en un plano superior y supraordenado al que es propio de la actividad contractual» ${ }^{40}$. El equilibrio contractual, roto con la modificación unilateral del contrato por el ejercicio de la reconocida potestad, se restaura no desde el contrato mismo, sino acudiendo a la técnica de la expropiación forzosa, aunque no siguiendo el procedimiento previsto legalmente para ella. Se mantiene el equivalente económico, propio del contrato, pero desde fuera del mismo.

Lo expuesto resulta suficiente para albergar serias dudas acerca de esa construcción doctrinal. Hasta qué punto no se está desnaturalizando, invalidando, la categoría jurídica del contrato y, cuando menos, del propio contrato civil que se toma como referencia. Los problemas que plantea el interés general, como justificación de la alteración del contrato, de lo pactado de un modo vinculante para Administración y particular, se resuelven desde fuera del contrato utilizando otras categorías jurídicas distintas. El contrato no ofrece la solución. ¿Es eso razonable para lo que puede pedirse a una categoría jurídica?

La generalidad del privilegio de autotutela, no expreso en el Derecho positivo, y sus consecuencias, revela que ese poder se corresponde, en definitiva, con una concepción doctrinal del Derecho administrativo formulada en el ámbito temporal del Estado liberal de Derecho, cuya pieza fundamental es el acto administrativo, como decision exécutoire, y se manifiesta en muchos de sus dominios: recuperación de oficio de bienes, presunción de validez, de veracidad de actas de inspección...

La construcción deja, al menos, insatisfacción y ha de constatarse que, pese a su influencia, no es asumida por todos los ordenamientos jurídicos, ni siquiera en Europa.

\section{La orientación alemana}

Es conocida la resistencia en Alemania al reconocimiento de un contrato administrativo como el descrito. La solución contractual, que tiene en cuenta la existencia de una ideológicamente poderosa Administración y la relevancia social de la burguesía, se formula de un modo diferente a Francia. El proceso de la unificación alemana bajo la batuta de Bismarck y la línea ideológica del idealismo ilustran acerca de los derroteros que seguiría el Derecho público alemán. Para HEgEL, «el Estado es la realización de la idea moral o ética». En esa órbita podrá ex-

40 Ibid., pág. 665 . 
plicarse que se construyera el acto administrativo al modo de la sentencia judicial ${ }^{41}$ y ha quedado descrita la resistencia del Estado al contrato con los particulares.

Los contratos celebrados por la Administración no presentarían ninguna especialidad respecto de los celebrados entre particulares: unos y otros están íntegramente sometidos al Derecho civil. Para ello se utiliza la figura del Fisco, un residuo histórico ${ }^{42}$ que se entiende porque, al fin y al cabo, en Alemania la Pandectística había supuesto el reconocimiento y valoración del Derecho romano. De otra parte, en el ámbito liberal del Rechstaat, la burguesía se encontraba más segura cobijada en el ámbito del Derecho privado.

\section{El Common Law}

Es conocido el escándalo que produjo en DicEY el régime administratif, al reconocer una jurisdicción especial para revisar los actos de la Administración. Es incompatible con los fundamentos de la Constitución americana. En esos ordenamientos los contratos suscritos por el Poder están sometidos al Derecho privado, lo que no es inconveniente para que jueguen cláusulas que no son normales en los contratos entre particulares, en razón de los intereses supraindividuales que deben procurar. Unas referencias serán suficientes para mostrar la realidad de la afirmación adelantada.

3.1. En el Reino Unido, en el caso citado del Anphitrite quedó claro que «la Corona no puede por un contrato trabar la libertad de la acción en materias que se refieren al welfare of state». De un modo más general, una autoridad no puede ser despojada de sus poderes y deberes; la «libertad de contrato» se ejerce para lo que no está prohibido legalmente, incluida la prohibición de ejercer el poder. La jurisprudencia ha de comprobar ese principio en cada caso. Como leadings cases se presentan el Ayr Harbour (1883), favorable a su admisión, y el Birkdale Electricity (1926), en contra ${ }^{43}$.

La incidencia del interés público en estos contratos sometidos al Derecho común es hoy una realidad, impulsada por la pertenencia a la Unión Europea, perceptible en la judicial review y una sección especial

41 Cfr. Otto MAYER, Derecho administrativo..., cit., págs. 82-83, aunque se reconoce que la expresión "acto administrativo» ha sido tomada de la terminología francesa.

42 Derecho..., págs. 59 y ss.

43 Cfr. J. L. Meilán GiL, La estructura..., págs. 73-78. 
de la High Court y constatada por la doctrina que se aleja de la posición de DicEY ${ }^{44}$.

En los EE.UU., la cuestión gira en torno a la interpretación de la contract clause anteriormente citada. Como atestiguará la jurisprudencia, la obligación a que se refiere es de origen y naturaleza civil, incorporada al contrato y formando parte de él ${ }^{45}$. La aplicación estricta de la cláusula en la era del juez Marshall causó alarma al sostener la invariabilidad del contrato. La reacción para reducir a sus estrictos términos el alcance de la cláusula - the rule of stricte construction- se orientó, aprovechando la pista dejada por el citado juez, en indagar cuál fue la intención, la voluntad de la Administración.

El leading case fue el citado Charles River Bridge v. Warren Bridge ${ }^{46}$. La cuestión a revolver es si la concesión (charter) por la que se autoriza a una compañía un puente con peaje impedía que se estableciera próximo a él otro libre de peaje. De acuerdo con la doctrina tradicional, la contestación debía ser negativa; pero la sentencia adopta una nueva perspectiva, influida por la idea del progreso ${ }^{47}$. El poder del Estado, se dirá, no puede detenerse por meras interpretaciones legales - debe aprovecharse de las luces de la moderna ciencia- ni debe impedirse por privilegios que fácilmente podrían constituir un obstáculo para el desarrollo del transporte a través de nuevas líneas. Casi setenta años después, en el caso Blair v. City of Chicago ${ }^{48}$ se sostendría que, en caso de dudas razonables, se resolverá a favor del State y si caben dos interpretaciones se adoptaría la que sea menos lesiva para él ${ }^{49}$.

La cuestión fundamental consistirá en interpretar qué ha de entenderse por impair the obligation en la muy amplia jurisprudencia, con vaivenes y votos disidentes en no pocas de las sentencias. En Home Building y Loan Ass v. Blaisdell ${ }^{50}$, un leading case se califica como tal, liberar o extinguir la obligación, derogar en lo sustancial los derechos contractuales sin destruir el contrato. La política de proteger los contratos contra el impairment presupone un gobierno que mantiene la adecuada autoridad para asegurar la paz y el buen orden de la sociedad.

\footnotetext{
44 Ibid. Cfr. X. CoDina GARCÍA-ANDRADE, «Introducción al régimen inglés de los contratos públicos», RAP, 194, 2014.

45 Walker v. Whitehead, 83 U.S. 314 (1873); Word v. Lovett, 313 U.S. 362.370 (1941).

4636 U.S. (11 Pet) 420 (1837).

47 Cfr. J. L. Meilán GiL, Progreso tecnológico y servicios públicos, Thomson-Civitas, 2006; sobre la cláusula de progreso de la ciencia, págs. 53 y ss.

48201 U.S. 400 (1906).

49 Un campo propicio para la aplicación de la regla es el de las exenciones de tributos. Ad exemplum, STerns v. Minnesota, 179 U.S. 232 (1900), en relación con terrenos afectos al ferrocarril.

50290 U.S. 398 (1934).
} 
Se trata de armonizar la prohibición constitucional del impairment con el «necesario residuo de poder», con «la reserva de atributos esenciales del poder soberano» ${ }^{51}$, un eco de la herencia británica. La finalidad de la cláusula, según la sentencia citada, es «estimular el comercio y el crédito proporcionando la confianza en la estabilidad de las obligaciones contractuales»; pero también el Estado posee la autoridad para salvar los intereses vitales del pueblo. Es necesario armonizar ambos objetivos. En ello pone énfasis la sentencia, cuando era corriente la interpretación estricta de la contract clause.

El derecho de proteger el general welfare del pueblo, que se concretaría en el poder de modificar o afectar a las obligaciones del contrato, «tiene su límite». La cuestión es conocer si el ejercicio de ese poder es necesario en cada caso. Saliendo al paso de una admisión generalizada se advierte que «nada indica que la contract clause no tiene sentido en la moderna jurisprudencia, que su limitación del poder es ilusoria». Lo corrobora al aplicarla on the instant case, ya que resulta claro que, desde el statutory language, el concreto convenant constituyó un contrato ${ }^{52}$. De otra parte, es doctrina frecuentemente sostenida que el State no es libre para imponer un drástico impairment cuando otros medios, evidentes y moderados, podrían servir de igual manera para sus propósitos

A los efectos aquí pretendidos será suficiente mostrar los diferentes títulos que se utilizan para justificar la no aplicación estricta de la contract clause o, sencillamente, para el impairment. La apelación al eminent domaine se hace por primera vez en $1848^{53}$, en una sentencia relativa a una concesión, en exclusiva, para construir un puente en una determinada localidad. Tal concesión, como toda otra forma de propiedad, está sujeta al superior poder del eminent domaine. El Estado de Vermont puede otorgar otra concesión a una compañía competidora de la anterior. El razonamiento se refuerza aludiendo a la soberanía del Estado y al carácter inalienable de sus principales poderes, incluso aunque existiere un acuerdo explícito de renunciar a ellos ${ }^{54}$.

Bajo el police power ${ }^{55}$ se acoge una variedad de casos que hacen difícil su definición precisa. El leading case se remonta a $1880^{56}$ y se re-

51 Home Building..., cit., y City of El Paso v. Simmons, 379 U.S. 497 (1965).

52 A favor de la aplicación de la cláusula, US Co. of New York v. New Jersey, 431 U.S. ( 1977).

53 West River Bridge Company v. Dix, 47 U.S. (G. How) 507.

54 Pennsylvania Hospital v. City of Philadelphia, 245 U.S. 20 (1917): «to restrain by contract would be a renuntiation of power to legislative for the preservation of society or to secure the performance of essential governmental duties».

55 Ibid.

56 Stone v. Mississippi, 101 U.S. 814. 
fiere a la concesión de una lotería. Dos años más tarde se prohíben las loterías en el Estado. La sentencia declara que puede retirar aquella concesión at will. La razón estriba en la obligación de los poderes públicos, que han sido establecidos para preservar la salud y la moral públicas. El impairment puede justificarse en el police power sólo cuando es razonable y necesario un important public purpose ${ }^{57}$.

En el caso Lynch v. United States (1934) se declara que: «The due process clause prohíbe a los Estados Unidos anular o desconocer sus contratos, salvo que la intervención se base en the federal police power or some other paramount power». La jurisprudencia llegará a decir que ni la contract clause ni la due process clause podrán impedir el poder del Estado para regular la salud, la seguridad, el buen orden, el confort y el general welfare de la comunidad ${ }^{58}$.

\section{RECONSTRUCCIÓN DE LA CATEGORÍA CONTRACTUAL}

De lo que acaba de exponerse resulta que desde posiciones constitucionales distintas, francesa y americana, se admite la posibilidad de modificar los contratos por el Poder. La diferencia es, no obstante, significativa. En el caso francés se parte de la potestas variandi de la Administración; en el americano, el punto de partida es la posición del ciudadano como parte en un contrato, protegido por la contract clause, que encuentra limitaciones por el ejercicio de una potestad. Puede parecer sutil la diferencia, pero influye en la construcción de la categoría jurídica. En Home Building, como se recordó, las modificaciones se realizan sin destruir el contrato, el único que conoce el ordenaminento americano; dicho de otro modo, esas modificaciones se encuentran ínsitas en el contrato, y por eso la jurisprudencia insiste en indagar cuál fue la voluntad del government en el concreto covenant, en cómo fue convenido. En el modelo francés derivan de una potestad ajena al contrato, de ahí que se afirme estar ante un contrato con diferencias, exorbitante, del civil y se manifiesta mediante un acto ejecutivo. Supone una desigualdad de las partes en el contrato, no aceptada, por diferentes motivos, en Alemania y en el Common Law. En todo caso, queda claro que el modelo francés del contrato administrativo no es de aceptación universal.

De esas apreciaciones ha de partirse para una reconstrucción jurí-

57 United States Trust Company of New York v. New Jersey, 431 U.S. 1 (1977). El Tribunal Supremo negó que pudiera apelar a ese poder, en contra del Tribunal Supremo de New Jersey.

58 Attlantic Coast Line R. Co. v. City of Goldsboro, 232 U.S. 548.558 (1914); Pensylvania Hospital, cit. 
dica de los contratos públicos. No se trata de modular un contrato civil, con probable desnaturalización de la categoría de contrato, sino de partir de lo que es esencial, definidor de todo contrato, cualesquiera que sean las partes que lo celebren. Tampoco creo que sea una solución la propuesta de explicar el contrato administrativo como un híbrido "acto contractual», un acto unilateral con efectos contractuales, se ha sostenido, al subrayar la importancia del acto de adjudicación del contrato por la Administración ${ }^{59}$.

El contrato administrativo es sencillamente un contrato, que no es modulación del civil. Uno y otro son manifestación de una única categoría jurídica, considerando el contrato como un supraconcepto, un oberbegriff, común a contratos entre particulares y a aquellos en que interviene la Administración, el government ${ }^{60}$. El elemento esencial que da lugar a la categoría es el duarum in idem placitum consensus, con la mutua vinculación anteriormente recordada y que supone una igualdad entre las partes que, en los contratos en que interviene la Administración, obviamente, no son iguales desde el punto de vista subjetivo.

Para hacer realidad la igualdad requerida por el contrato la Administración no tiene que revestirse con una personalidad distinta para acceder a él (Alemania), ni tampoco ejercer potestades ajenas a lo contratado (Francia), sino ejercer los derechos y obligaciones que se contienen en el contrato. En ese sentido, el particular, como parte en el contrato, no puede ser considerado como mero ciudadano destinatario del ejercicio de una genérica potestad. En otros términos, Administración y particulares se encuentran en el contrato en igualdad de condiciones.

En sede doctrinal se ha mantenido que la desigualdad de las partes en el contrato no es exclusiva del contrato administrativo; se daría también en el Derecho civil sin que haya de negarse la naturaleza contratual, poniendo como ejemplo los contratos de adhesión ${ }^{61}$. No es ésa mi opinión. Sin extenderme en la cuestión, el contrato de adhesión es

59 J. L. Monedero GIL, Doctrina del contrato de Estado,Instituto de Estudios Fiscales, Madrid, 1977; J. L. MARTínez LóPEZ-MuÑIz, "Naturaleza de los contratos públicos a la luz del Derecho español: Su fundamento y consecuencias», en Derecho administrativo. Homenaje al profesor M. J. Marienhoff, dir. J. C. CASAGne, Buenos Aires, 1988, págs. 947-969.

60 Desde otra perspectiva sienta la misma tesis, que reconforta, R. F. BACELLAR Filho, "A incidencia do direito civil nos contratos administrativos», en El Derecho Administrativo en perspectiva, T. I, Ediciones Rap, Buenos Aires, 2014, pág. 53: «pensamos que o contrato é uma categoría jurídica que nao pertence nem o Direito privado nem o Direito público, com caráter de exclusividade. Insere-se no Direito e como tale debe ser estudado». J. BARNÉs, buen conocedor del Derecho comparado, lo plantea como interrogante: «¿Hacia un supraconcepto o régimen de contratación administrativa como categoría comprensiva de la contratación pública y privada? Principios y valores jurídico-administrativos en tránsito", en Contratación Pública, vol. II, Adrus Editores, Lima, 2013, págs. 111 y ss.

61 Cfr. S. Martín-Retortillo, El Derecho civil en la génesis del Derecho administrativo y de sus instituciones, Instituto García Oviedo, Sevilla, 1960, págs. 173 y ss. 
un contrato sin «tratos» previos. En cambio, en los contratos públicos pueden existir negociaciones, como reconoce el Derecho comunitario. En el procedimiento de licitación con negociación se prevé presentación de una oferta inicial por los operadores económicos invitados, negociación con los licitadores de las ofertas iniciales y las ulteriores presentadas por éstos. El diálogo competitivo se entabla, precisamente, para determinar y definir los medios más idóneos para satisfacer las necesidades del poder adjudicador.

La participación de los particulares en lo que va a ser, en definitiva, el objeto del contrato revela una diferencia con la concepción tradicional del contrato administrativo. La Administración no es la única poseedora del conocimiento técnico. El desarrollo tecnológico y científico rebasa el poder de la Administración. Es un fenómeno que supera de modo espectacular el ambiente en el que se originó la «cláusula de progreso» en el siglo XIX. Por ello, hoy más que entonces, ni la Administración ni los ciudadanos pueden renunciar a las ventajas de ese desarrollo: «la técnica más avanzada» 62 .

La igualdad no tiene que impedir la realización del interés general que la Administración debe servir. Dicho de otra manera, el interés general que justifica el contrato no debe desnaturalizar la relación contractual, con su conjunto de derechos y obligaciones. Por eso, me he manifestado en contra de la permanencia de las prerrogativas de la Administración en los contratos públicos. Lo que en la construcción del contrato administrativo, tanto en la teoría como en el Derecho positivo, se realiza con el ejercicio de potestades extracontractuales, en la que estoy defendiendo se llevaría a cabo dentro del contrato en virtud de los derechos y obligaciones en él establecidos. El interés general no tiene por qué ser garantizado, en definitiva, por un acto unilateral con efectos ejecutivos. Ésa es la fundamental diferencia ${ }^{63}$.

El interés general se limita al contrato; no es una manta que lo cubre todo ${ }^{64}$. La concreción de ese interés general se realizará en la preparación y adjudicación, o formalización, del contrato. En ello radica

62 Cfr. J. L. Meilán GIL, La «cláusula de progreso» en los servicios públicos, IEA, Madrid, 1968, con Prólogo de J. L. Villar Palasí, desarrollada y puesta al día en Progreso tecnológico..., 2006.

63 Con expresa referencia a mi tesis, G. Gimeno Feliú, El nuevo paquete legislativo comunitario sobre contratación pública. De la burocracia a la estrategia, Thomson Reuters, 2014, pág. 13, por nota, dice: «En el fondo, se diluye la categoría del contrato administrativo caracterizado por un derecho exorbitante, de tal manera que el enigma del contrato administrativo (en sugerentes palabras de Ariño Ortiz...) parece resolverse hacia una regulación del contrato público ya no justificada en el imperium, sino en la transparencia para preservar un modelo de concurrencia».

64 El interés general de un Estado puede ser contrario al Derecho de la UE, como reconoce abundante jurisprudencia. 
la peculiaridad de los contratos públicos, que ha quedado desatendida en la construcción doctrinal expuesta sobre el contrato administrativo al poner el acento en las exorbitancias en la ejecución del contrato y su justificación. Y cuando se ha atendido a ella, por razones procesales, se han acuñado los actes detachables por razones procesales. Otro indicio de que las categorías jurídicas no deben construirse sobre esa conveniencia. Lo que tiene que estar asegurada es la revisión judicial, con su carácter de independencia. Que no es esencial el modo en que se realiza esa revisión lo manifiesta la misma realidad del contrato administrativo. En Francia va ligado a una jurisdicción especial por las razones políticas recordadas; no ocurre lo mismo en otros países que han seguido el paradigma del contrato administrativo francés ${ }^{65}$.

La importancia de esa llamada a veces, de una manera equívoca, etapa «precontractual» viene a ser determinante de la singularidad de los contratos públicos ${ }^{66}$. En ese sentido forma parte del contrato, aunque algunos ordenamientos den pie para separarlos, al distinguir licitaciones y contrato administrativo ${ }^{67}$. Ciertamente, la presencia de la Administración es significativa, pero no tanto por estar investida de potestades cuanto por exigencias de servir el interés general y por el modo de manifestarse. Por lo que se refiere a este último punto, se realiza mediante un procedimiento integrado por actos cuya inexistencia o no conformidad a Derecho invalidan el acuerdo en que se concreta el contrato: anuncio de licitación, de admisión de los candidatos, selección, adjudicación, o equivalentes, en cuyo análisis no es ocasión de entrar, a los que anteceden actuaciones preparatorias ${ }^{68}$. Ésa es la manera de manifestar su «voluntad» y por eso se manifiesta en todos los contratos de la Administración, incluidos los que se califican de privados por estar sometidos al Derecho privado y no al administrativo, según la concepción francesa del contrato administrativo ligado a potestades exorbitantes $^{69}$. Desde esta perspectiva, que se refiere a actos objetivos,

65 Cfr., ad exemplum, C. A. Bandeira de Mello, Curso de Direito Administrativo, 17. a ed., Malheiros Editores, São Paulo, págs. 571 y ss., en las que se reconoce el paradigma francés, y las págs. 836 y ss., sobre el control jurisdiccional; Odete MEDAur, Direito administrativo moderno, 13. ${ }^{\mathrm{a}}$ ed., Revista dos Tribunais, São Paulo, 2009, págs. 404-445.

66 Un informe de la Comisión Nacional de los Mercados y la Competencia de 5 de febrero 2015, «Análisis de la contratación pública en España: oportunidades de mejora desde el punto de vista de la competencia», destaca la necesidad de mayor acceso, transparencia y publicidad; falta de evaluación de la eficiencia económica y de la competencia efectiva; necesidad de simplificar los procedimientos de contratación.

67 Cfr. C. A. Bandeira de Mello, Curso..., capítulos IX y X; Odete Medaur, Direito..., págs. 10 y 11 .

68 Cfr. J. L. MeILÁn GiL, La estructura..., págs. 211 y ss.

69 No sin razón, se ha puesto en duda que se trate de dos categorías diferentes. Cfr. E. Soto KLOSS, «La contratación administrativa: un retorno a las fuentes clásicas del contrato», $R A P$, 
pueden superarse incertezas que se desprenden de la jurisprudencia americana al indagar la «voluntad» del government. En realidad, esa «VOluntad» se deduce de los términos expresados en la oferta. Lo fundamental en el acto del poder contratante, adjudicador en la terminología comunitaria, es su conformidad o no con el Derecho, en lo que no juega la intencionalidad del agente que lo expresó, que se prueba en el caso extremo de la desviación de poder; podrá dar lugar a un delito — prevaricación-cuando existe intencionalidad desviada ${ }^{70}$.

La decisión de la Administración, en todo caso, resulta ampliamente predeterminada por el bloque normativo que integran la ley y los pliegos de condiciones administrativas y técnicas o equivalentes. Su justificación estriba en cumplir con la misión encomendada a la Administración de servir el interés general. Desde este punto de vista van a cobrar relevancia jurídica principios como razonabilidad, proporcionalidad, eficiencia, transparencia, no discriminación, que se han reforzado en el Estado social y democrático de Derecho.

Esto es lo diferencial respecto del contrato entre particulares, en el que el principio dominante es la autonomía de la voluntad que ha de desenvolverse en el marco de la ley, solo un límite para aquélla. Esa actuación de la Administración que conduce a la formalización del contrato tiene, no obstante, explicación en elementos característicos de los contratos, como el objeto, precio y valor estimado o cuantía. No resulta anómala en la actividad contractual de la Administración.

Se corresponde con el procedimiento que, como parte, ha de desarrollar la Administración para fijar la decisión que constituirá la oferta contractual. El objeto del contrato es determinante y condicionante de esa decisión que conduce a la selección del contratista asegurando la concurrencia ${ }^{71}$. Aquellos elementos, fundamentalmente el objeto, condicionan no solo la elección del contrato, sino también la modalidad del procedimiento a seguir. La Administración no puede con-

86, 1978, pág. 582. En realidad, la distinción proviene de que en la concepción francesa del contrato dministrativo la Administración ostenta potestades extracontractuales, incompatibles con el contrato civil. Ningún inconveniente existe a que en la fase de licitación y adjudicación del contrato no se haga referencia al contenido de las citadas prerrogativas; basta la que se hace al Derecho privado, que no las admite. En todo caso, para la interpretación del contrato ha de tenerse en cuenta que se encuentra institucionalmente implícito en toda actuación de la Administración el servicio al interés general que le vincula; es la diferencia con la libertad que tiene el particular en el ejercicio de su voluntad.

70 Cfr. J. L. Meilán GIL, «El acto administrativo como categoría jurídica», en Categorías..., págs. 83 y ss.

71 Una vieja aspiración que consta en el Decreto de Bravo Murillo de 1852, con intención moralizadora: «establecer ciertas trabas saludables, evitando los abusos fáciles de cometer en una materia de peligrosos estímulos y de garantizar a la Administración contra los tiros de la maledicencia». 
tratar con cualquiera, ni puede adjudicar el contrato en cualesquiera condiciones, más allá de principios generales exigibles al ciudadano ideal. La decisión de la Administración contratante resulta ampliamente predeterminada por exigencias del interés general al que ha de servir y que no alteran la categoría jurídica del contrato.

La concepción del contrato administrativo, con prerrogativas de la Administración y centrada fundamentalmente, por propia declaración, en la ejecución del contrato, es coherente con la del Derecho administrativo entendido como Derecho de la Administración, dominus del interés general. Desde el inicio de mi actividad académica he puesto el acento en los intereses generales, en una orientación ratione materiae o funcional ${ }^{72}$. No todo lo público forma parte de la Administración como complejo orgánico ${ }^{73}$. Por eso me he resistido a integrar a las Corporaciones públicas en la generalizada rúbrica de Administración corporativa $^{74}$. Lo objetivamente administrativo no está necesariamente incorporado en la Administración sujeto, como evidencia lo que sucede con determinadas actividades de poderes del Estado diferentes del tradicionalmente denominado Poder ejecutivo, que abarca Gobierno y Administración ${ }^{75}$.

Resultaría anómalo que se les reconociese prerrogativas administrativas a entes que no estén integrados en la Administración territorial ${ }^{76}$. Cualquiera que sea su amplitud, la realidad de entes contratantes que no se reconocen como Administración pública, aunque no constituya la razón fundamental, contribuiría a reforzar la tesis de la supresión de prerrogativas cuando actúa la Administración. Esa tesis que he defendido no es, repito, el triunfo del interés privado sobre el público, que sigue

72 Resulta reconfortante comprobar cómo exponentes de aquella corriente, después de muchos años de aceptar disciplinadamente la definición del Derecho administrativo como Derecho estatutario de la Administración, insistan ahora en el interés general, que conseguí introducir en la Constitución de 1978. Cfr. J. L. CARRO FERNÁNDEZ-VALMAYOR, «Reflexiones sobre las transformaciones actuales del Derecho público, en especial del Derecho administrativo», RAP, 193, 2014. J. BARNÉs, “¿Hacia un supraconcepto...?», se pregunta: «¿Estaríamos entonces ante el abandono de una concepción subjetiva del Derecho administrativo en beneficio de una comprensión funcional, cuando menos en el ámbito de la contratación?». La respuesta, concluye, "parece ser afirmativa».

73 El mutualismo laboral. Un estudio jurídico, CSIC, Madrid, 1963.

74 Cámaras de Comercio, Industria y Navegación, Colegios Profesionales, Organización de Ciegos Españoles, Corporación de Derecho público de carácter social...

75 No es ésa la orientación del TRLCSP, cuyo artículo 3 los considera Administraciones públicas «a los efectos» de esa Ley en cuanto a su actividad contractual.

76 Es la única que en el Derecho español tiene la potestad expropiatoria en la que se basa la doctrina criticada para justificar las prerrogativas en los contratos administrativos. En el sentido del texto, la STJCE de 20 de septiembre de 1988, asunto 31/87, Gebroeders Beenjes BV contra Estado de los Países Bajos: «el organismo en cuestión tiene la condición de poder adjudicador, aunque no esté integrado en la Administración del Estado». El punto de partida fue que «la noción de Estado debe ser objeto de una interpretación funcional». 
siendo prevalente y determinante de los contratos públicos, sino el triunfo del Derecho frente a la prepotencia y la corrupción. En no pocas ocasiones, el ejercicio de la prerrogativa encubre deficiencias de la Administración en la preparación del contrato con aquiescencia del contratista, como ha reconocido el Consejo de Estado ${ }^{77}$.

El mantenimiento de las potestades de la Administración en el contrato, manifestadas por la emisión de un acto unilateral con efectos ejecutivos inmediatos, viene a confirmar el ámbito propio del Estado liberal del que es deudora la construcción. La solución definitiva de la discrepancia a través del contencioso-administrativo resulta poco practicable para los contratistas poco poderosos y explica el proporcional escaso número de casos planteados ante los tribunales ${ }^{78}$. Las discrepancias o controversias surgidas durante la ejecución del contrato podrían resolverse por un órgano independiente mediante un procedimiento rápido y transitoriamente vinculante para ambas partes del contrato, como se hace ahora para las que se sucitan en relación con la fase de licitación y adjudicación del contrato ${ }^{79}$.

\section{El test del Derecho de la Unión Europea}

La reconstrucción de los contratos públicos que he realizado coincide en lo fundamental con lo que contienen las Directivas comunitarias de contratos ${ }^{80}$, en cuanto a la orientación metodológica expuesta. La Directiva relativa a la ajudicación de contratos de concesión es nueva. Lo que se entiende por concesión y lo que no debe considerarse concesiones, constituyen una reafirmación de la dialéctica acto-contrato

77 Cfr. J. L. MeILÁn GIL, «Las prerrogativas...».

78 Ocurre también en el Reino Unido. Cfr. X. Codina GARCÍA-ANDrAdE, «Tutela judicial y sistemas de recursos en la contratación pública inglesa», RAP, 195, 2014.

79 Cfr. J. L. MeIlán GIL, «Las prerrogativas... »; Marta García Pérez, «Medios de solución de controversias contractuales en el Derecho español», en Contratación Pública, vol. II, Adrus Editores, Lima, 2013, págs. 137 y ss.

80 Directiva 2014/23 UE del Parlamento Europeo y del Consejo, de 26 de febrero de 2014, relativa a la adjudicación de contratos de concesión, y Directiva 2014/24 UE del Parlamento Europeo y del Consejo, de 26 de febrero de 2014, sobre contratación pública, que deroga la Directiva 2004/18 CE, sobre contratos públicos de obras, suministros y servicios. Las citas en el texto se refieren a aquellas dos Directivas. Se tendrá en cuenta su contenido solo desde el punto de vista del presente trabajo. El ámbito objetivo queda claramente determinado por las Directivas. «Las normas de la Unión sobre contratación pública no tienen por objetivo regular todas las formas de desembolso de fondos públicos, sino únicamente aquellas destinadas a la adquisición de obras, suministros o servicios prestados mediante un contrato público... sin que ello implique necesariamente una transferencia de propiedad a los poderes adjudicadores» (cdo. 4 D. 2014/24), «con independencia de que las obras, los suministros o los servicios estén destinados o no a un fin público». 
por la que comenzó la aproximación académica a los contratos públicos, y permite confirmar algunas decisiones judiciales americanas para liberarse de una aplicación estricta de la contract clause y controversias doctrinales ${ }^{81}$. Las concesiones son contratos a título oneroso, de ejecución de obras o prestación de servicios que tienen como contrapartida de la adjudicación el derecho a explotarlos, en conjunción o no con un pago, llevando o no transferencia de la propiedad. En cambio, no deben considerarse contratos «ciertos actos de los Estados miembros como las autorizaciones o licencias en virtud de las cuales el Estado o una autoridad pública establece las condiciones para el ejercicio de una actividad económica» ${ }^{82}$; dogmáticamente son actos necesitados de aceptación.

Lo mismo podría decirse de la importancia atribuida a la preparación y adjudicación si se tiene en cuenta que sus principios se aplican a todos los contratos públicos ${ }^{83}$, pero para los que superen un determinado valor han de elaborarse disposiciones nacionales «a fin de asegurar que esos principios tengan un carácter práctico y que la contratación pública se abra a la competencia» (cdo. 1). En ese sentido se reconoce con reiteración que «respetar el principio de igualdad de trato responde a la esencia de las directivas en materia de contratos públicos».

En cuanto a poderes adjudicadores, su definición incluye el Estado, las autoridades regionales o locales, organismos de Derecho público y sus asociaciones. Para lo que aquí interesa, lo fundamental es que son entes ligados al interés general y su procura, que se enfatiza en relación con los citados organismos: han de haber sido específicamente creados "para satisfacer necesidades de interés general que no tengan carácter industrial o mercantil» (art. 2).

La orientación comunitaria no responde a preocupaciones dogmáticas, sino al objetivo de hacer realidad un mercado único coherente con las libertades del Tratado de la UE, en particular la libre circulación de mercancías, de establecimiento de prestación de servicios. En ese sentido ha supuesto realmente un meeting point de ordenamientos jurídicos con tradiciones diversas. Por eso el principio de igualdad de trato se erige en la matriz de otros: no discriminación, reconocimiento mu-

81 Cfr. C. A. Bandeira de Mello, Curso..., pág. 572.

82 Considerandos 11 y 14 de la Directiva 2014/23.

83 Un leading case, STJ de 7 de diciembre de 2000, asunto Telaustria, C-324/98. Sobre el tema, C. VIANA, Os princípios comunitarios na contrataçao pública, Coimbra Editora, 2007, con Prólogo mío, que fui orientador de la tesis de doctorado. En el mismo sentido, J. A. MorEno MolinA, «El sometimiento de todos los contratos públicos a los principios generales de contratación», en Liber amicorum Tomás Ramón Fernández, T. II, Thomson Reuters, 2012. 
tuo, transparencia, proporcionalidad, como es ya consolidada doctrina jurisprudencial y científica ${ }^{84}$.

Toda la preparación del contrato y el procedimiento que llega hasta la formalización de aquél ha cobrado una relevancia máxima ${ }^{85}$, obligando a todos los Estados miembros. Esa fase tiene como misión fundamental la determinación del interés general, que no es algo aleatorio, ante el cual el poder contratante pueda ser neutral. Por eso, las Directivas se preocupan de precisar las obligaciones de ese poder con los ciudadanos y no solo con el contratista. Hasta tal punto resulta prevalente esa etapa que desde ella se influye en la ejecución del contrato.

La modificación del contrato, por ejemplo, es el cumplimiento de un derecho-obligación integrado en él; no es el ejercicio unilateral de una potestad ajena al mismo. Las modificaciones han de estar previstas en los pliegos iniciales de la contratación, en cláusulas de revisión claras, precisas e inequívocas; no pueden alterar la naturaleza global del contrato (art. 72). Porque, en definitiva, se estaría vulnerando el principio de igualdad al impedir la concurrencia en un realmente nuevo contrato; en otros términos, porque la modificación pretendida «exige un nuevo procedimiento de contratación».

Otro tanto podría decirse respecto de la posibilidad de que los poderes adjudicadores establezcan condiciones relativas a la ejecución del contrato, subrayando, de manera significativa , "siempre que estén vinculadas al objeto del contrato»y, por supuesto, "se indiquen en la convocatoria de licitación o en los pliegos de contratación» (art. 70). En la misma línea, la exigencia de «cierta transparencia en la cadena de subcontratación» (art. 71).

La predeterminación de la decisión del poder adjudicador se manifiesta con claridad. La Administración no puede elegir libremente el tipo de contrato: contrato de concesión de obra en lugar de contrato de obra, por ejemplo. El contrato de concesión, por primera vez objeto de una Directiva, ha de referirse a servicios de interés económico general, no a los de interés social ${ }^{86}$. No es, por tanto, discrecional, alegando el

84 Una exposición amplia en la STJUE de 16 de septiembre de 2013 (Comisión v. Reino de España); apud J. M. ${ }^{a}$ Gimeno Feliú, El nuevo paquete..., págs. 20-21, que la considera un leading case.

85 La importancia de esa fase incide en el aspecto hacendístico que ha estado siempre presente en la contratación. Las concretas previsiones de las Directivas de 2014 han de constituir normas aplicables al presupuesto general de la UE. En ese sentido se ha manifestado el Dictamen del Tribunal de Cuentas Europeo 1/2015, de 15 de enero.

86 En realidad, viene a corresponder a la concepción de servicios públicos que he mantenido desde siempre al sostener que tenían un carácter económico para ser objeto de concesión a particulares, la burguesía de los negocios, que el progreso técnico hacía posible. Cfr. J. L. Meilán Gil, Progreso tecnológico y servicios públicos, Thomson-Civitas, 2006. 
interés general, utilizar el contrato de concesión, porque de esa manera un Estado miembro de la UE no computa el importe del contrato como déficit. La asunción del riesgo no es igual en el contrato de obra que en el de concesión de obra pública. En este la adjudicación de la concesión, en todo caso, implica la transferencia al concesionario de «un riesgo operacional» 87 .

Tampoco puede elegir libremente el procedimiento. En ese sentido, puede establecerse un procedimiento de licitación con negociación (art. 26.4) o un diálogo competitivo (art. 30) en las situaciones previstas por la Directiva, porque no puede hacerse de otra manera: naturaleza, complejidad jurídica o financiera, riesgos inherentes o porque el poder adjudicador no puede establecer con suficiente precisión las especificaciones técnicas. En su justificación (cdo. 42), la Directiva subraya el aumento significativo de su empleo que es singularmente útil en aquellos casos en que los poderes adjudicadores no están en condiciones de definir los medios ideales para satisfacer sus necesidades o evaluar las soluciones técnicas, financieras o jurídicas que puede ofrecer el mercado, sobre todo en los proyectos innovadores, en la ejecución de grandes proyectos de infraestructuras de transporte integrado o en las redes o los proyectos informáticos de gran tamaño que requieran financiación completa y estructurada. Esa tesis se confirma por vía negativa, al prohibir los procedimientos de licitación con negociación o el diálogo competitivo para los servicios o suministros disponibles en el mercado. También al exigir que se motive por qué no existen otras alternativas cuando se utilizan excepcionalmente procedimientos negociados sin publicación.

En todo caso, los nuevos requerimientos de la investigación, de la innovación, incluidas la innovación ecológica y social (cdo. 47), que ocupan un lugar central en la Estrategia Europea 2010, deben figurar previamente a la adjudicación del contrato. Y ésta ha de realizarse a la oferta económicamente más ventajosa atendiendo al cálculo del «coste del ciclo de vida» que incluye «aspectos cualitativos, medioambientales y/o sociales vinculados al objeto del contrato», todo lo cual, in-

87 Artículo 5.2.b) de la Directiva 2014/23. En el caso de contratos entre el sector público y el sector privado, que el borrador de Anteproyecto de la LCSP suprime por su escasa utilidad y no figuraba como tal en la Directiva de 2004, su artículo 11 concreta que solo podrán celebrarse cuando previamente se haya manifiesto públicamente que "otras fórmulas alternativas de contratación no permiten la satisfacción de las necesidades públicas», y de un modo positivo cuando permite, por ejemplo, «aportar soluciones más avanzadas y económicamente más ventajosas que las existentes en el mercado». La excepcionalidad viene determinada por la contraprestación a percibir por el contratista colaborador «que se satisfará durante toda la duración del contrato y que podrá estar vinculada al cumplimiento de determinados objetivos de rendimiento». 
cluido el método utilizado, ha de constar en los pliegos de la contratación (arts. 67 y 68).

Nada de todo eso supone alteración de lo que define un contrato. Se constata en la relevancia que tiene el objeto del contrato como delimitador de la actuación de la Administración al servicio del interés general que procura. Se ha citado en relación con el establecimiento de condiciones para la ejecución del contrato. También al establecer los requisitos de capacidad económica y financiera para la admisión de licitadores (cdo. 83); la remisión a etiquetas como la ecológica para incorporar las características que las definen, en esa materia medioambiental o social o de otro tipo, solo se admite si están vinculadas al objeto del contrato. Está presente también en la posibilidad de dividir grandes contratos en lotes. Tiene como objetivo claro y prevalente hacer más fácil el acceso de las PYMES a la contratación pública, pero siempre que no conlleve el riesgo de restringir la competencia o «socavar la ejecución del contrato» (cdo. 78). Desde el punto de vista de la categoría jurídica, podría decirse, sin que se altere el objeto del contrato.

Característica propia de todo contrato es el equilibrio de lo pacta$\mathrm{do}^{88}$. Ese equilibrio no resulta negado, ni siquiera en el contrato de concesión, en el que el poder adjudicador, como se adelantó, transfiere al contratista un «riesgo operacional», que se refiere a condiciones normales de funcionamiento. Se trata de contratos a título oneroso. La contrapartida para el contratista es el derecho a explotar las obras o los servicios objeto del contrato, sin más o en conjunción con un pago. Ese riesgo supone "una exposición real a las incertidumbres del mercado» (art. 5.1.b) . Un riesgo que se acepta como normal en el objeto del contrato y que asume incluso el poder adjudicador cuando se ha comprometido a un pago (cdo. 18). Los riesgos pueden compartirse.

Esa normalidad del mercado se relaciona con la duración de la concesión, que en todo caso no podrá exceder de la «tasa de retorno» prevista (rate of return): costes, recuperación de inversiones, rendimiento sobre el capital invertido, y es de subrayar que esos cálculos se realizan como necesarios "para alcanzar los objetivos contractuales específicos» (art. 18).

Para los funcionamientos anormales desde el punto de vista de lo pactado, además de lo tradicionalmente previsto en caso de fuerza mayor, puede aplicarse el principio o cláusula rebus sic stantibus, con las

88 Un libro señero, cuya elaboración seguí de cerca, desde la concepción tradicional de los contratos administrativos, es el de G. ARIÑo, Teoría del equivalente económico en los contratos administrativos, IEA, Madrid, 1968. 
mismas o análogas exigencias que se admitan para el contrato civil ${ }^{89}$. Quizá no sería necesario acudir a las tradicionales y bien conocidas causas de restablecimiento del equilibrio económico por el ejercicio de la potestas variandi ni el factum principis. Desde la perspectiva que he expuesto, el poder contratante no tendría aquella potestad. El reequilibrio viene exigido por lo pactado en el caso de las modificaciones previstas en el contrato, como consecuencia de lo dispuesto en el bloque normativo, inluidos los pliegos de condiciones, en cuyo ámbito tienen cabida "pactos, cláusulas y condiciones, siempre que no sean contrarios al interés público, al ordenamiento jurídico y a los principios de la buena administración ${ }^{90}$, no impedido por la Directiva, que, además, como se ha recordado, admite el diálogo competitivo y el procedimiento negociado sin publicación previa.

En el factum principis, con el que intenta justificarse un pretendido poder del Rey, ahora de la Administración, de quebrantar los pactos, se trata de medidas administrativas de carácter general que no pretenden modificar directamente el objeto del contrato, pero inciden sobre él haciéndolo más costoso para el contratista ${ }^{91}$. No es cuestión de extenderse sobre esta discutida figura. En lo que hay acuerdo es que son ajenas al contrato. Si proceden de la Administración, para no entrar en debate sobre otra procedencia, no provendrían de ella en tanto parte de un contrato, de acuerdo con la posición que vengo sosteniendo.

Desde la construcción tradicional, esta cláusula se instrumenta como respuesta al ejercicio de potestades de la Administración en el contrato. Responde a la indiferenciación de la Administración autora de la decisión y de la Administración contratante, titular de potestades ajenas siempre al contrato, incluso cuando sea parte de un contrato. Como consecuencia de la tesis que estoy sosteniendo habría que concluir que los supuestos a que se refiere el «hecho del príncipe» operan, en todo caso, para las dos partes, no solo para el contratista; ambas se encuentran igualmente vinculadas por el contrato. Así se reconoce en la reforma de la LCSP española ${ }^{92}$. Desde la igualdad de la vinculación del contrato para las dos partes, lo decisivo es el carácter objetivo de la

\footnotetext{
89 STS de 17 de mayo de 1957.

90 Artículo 25 del TRLCSP (art. 34 del Borrador del Anteproyecto de su reforma).

91 En ese sentido, E. García de EnTERría, Curso..., pág. 711.

92 El artículo 288.4 del Borrador del Anteproyecto de la LCSP corrige, en sentido favorable a lo sustentado en el texto, el homólogo artículo 282.4: «Se deberá restablecer el equilibrio económico del contrato, en beneficio de la parte que corresponda... cuando actuaciones de una Administración Pública competente — no de la Administración contratante — por su carácter obligatorio para el concesionario determinaran de forma directa la rupura sustancial de la economía del contrato».
} 
alteración del equilibrio del contrato, independiente del comportamiento de las partes. El interés general, ínsito en el contrato, requiere un restablecimiento del equilibrio que resultó afectado por razones de interés general ajenas al contrato.

\section{A LA BÚSQUEDA DE UN MEETING POINT EN LA CONTRATACIÓN PÚBLICA}

Las Directivas europeas han supuesto ya un punto de encuentro entre los ordenamientos jurídicos europeos en materia de contratos públicos. El procedimiento de preparación y adjudicación y formalización del contrato ha sido el elemento clave, con sus principios de igualdad de trato y no discriminación, de publicidad y transparencia. Estos principios han sido fundamentales. No bastaba que existiesen instrucciones de carácter interno a los entes contratantes ${ }^{93}$, que obviamente debían ser de conocimiento de los contratistas, en las que constaba la oferta del ente público. Había un déficit de igualdad y de publicidad y de transparencia fundamentales para el mercado de la UE. Por eso, tanto Alemania como el Reino Unido tuvieron que cambiar sus ordenamientos, porque las Directivas son de obligada transposición para los Estados miembros de la $\mathrm{UE}^{94}$.

Las Directivas no imponen un sistema judicial a los Estados. Aunque no tratan de regular la ejecución del contrato, el procedimiento citado limita la modificación del contrato porque puede vulnerar el principio de igualdad, la alteración del objeto del contrato; tambien puede contener precisiones sobre su ejecución. Ese procedimiento, con sus diversas fases, concreta la oferta del poder adjudicador que con la decisión del particular constituye el contrato. No es preciso apelar a potestades extracontractuales.

Esa orientación coincide en principios y en el iter de los contratos con el Agreement on Governmental Procurement del anexo IV del Acuerdo de Marrakech, por el que se constituyó la Organización Mundial del Comercio. El interés de la UE se manifestó en su día por asumir como parte del ordenamiento comunitario ese Acuerdo. Se ha confirmado en relación con el Acuerdo revisado, que se renovó por decisión del Consejo de la UE de 2 de diciembre de 2013 mediante un protocolo ${ }^{95}$. La Directiva 2014/24, al prever la revisión periódica de los umbrales establecidos para su aplicación a los contratos, dispone que se

93 Procurement Regulations, Verdingunsordnungen.

94 Cfr. J. L. Meilán GiL, La estructura..., págs. 100 y ss.

95 Protocolo publicado en el DOUE de 7 de marzo de 2014. 
verificará si «corresponden a los umbrales fijados en el Acuerdo de la Organización Mundial del Comercio sobre Contratación Pública» (art. 6.1) y en el caso de que, como consecuencia de previstas negociaciones sobre el Acuerdo, se hubiesen modificado los umbrales, la Comisión de la UE realizará la propuesta para modificar los fijados en la Directiva ${ }^{96}$. Hasta ahí llega la sintonía entre la UE y la OMC. De otra parte, la tesis que ha venido exponiéndose, en la que no juegan extracontractuales potestades exorbitantes, haría más fácil el arbitraje ${ }^{97}$, ampliamente utilizado en la contratación internacional y que no es ajeno al modo de resolverse las diferencias en la OMC con participación de expertos independientes ${ }^{98}$.

A la luz de lo expuesto, no parece que sea imposible encontrar un punto de encuentro desde el punto de vista americano, no obstante la complejidad de su regulación por la variedad de las Agencias ${ }^{99}$. La dificulad proviene no tanto de los principios como de la no uniformidad de la preparación del contrato y de la revisión jurisdiccional de éste ${ }^{100}$, asunto que para la UE no es fundamental. Las facultades que equivalen a las prerrogativas de la Administración se introducen como cláusulas en los contratos, derivan de ellas. Así empezó a reaccionarse ante la inicial interpretación estricta de la contract clause, o son cláusulas estandarizadas o reproducción de lo que figura en las procurement regulations publicadas en el Federal Registrer. Desde la tesis aquí desarrollada formarían parte del bloque normativo de la actividad contractual de la Administración. En ese sentido, el código o sistema Federal Acquisition Regulation (FAR) está fundamentalmente dirigido a «un imaginario y real administrador», el Contracting Officer, instrucciones para el personal del government, para la interpretación, pero puede ir más allá. Las regulations tienen «fuerza y efecto de ley» si son autorizadas por el Congreso $^{101}$. El órgano de la Administración solo tiene competencia — shall - para contratar de acuerdo con lo dispuesto en la regulation

96 Considerando 134 de la Directiva.

97 Claramente a favor, Marta GARcía PÉREz, "Medios de solución de controversias....».

98 Cfr. J. L. MeILán Gil, Una aproximación... Cfr. J. Danós OrdóÑEZ, «Los convenios de estabilidad jurídica o también denominados contratos leyes en el Perú», en Contratación Pública, Adrus Editores, Lima, 2013, págs. 615 y ss.: tienen naturaleza civil, lo que facilita acudir al CIADI.

99 Resulta obvio que no puede entrarse en un examen mínimamente pormenorizado. Cfr. John CiBInIC Jr., Ralph C. NASH Jr. y Christopher R. Yukins, Formation of Government Contracts, $4 .^{\text {a }}$ ed., The George Washington University, 2011. Los contratos públicos de las Directivas europeas se corresponden con algunas de las categorías del government procurement americano.

100 Ibid., se ilustra ampliamente.

101 Chrysler Corp. v Brown, 441 U.S. 281 (1979). Se reconoce que existe incertidumbre: ibid., págs. 59-60. 
existente en el momento de la celebración del contrato. Las cláusulas contenidas en las regulations han de incluirse, por tanto, en los contratos correspondientes ${ }^{102}$.

La jurisprudencia americana ha tenido que enfrentarse con el problema de la no inclusión de una de esas cláusulas previstas normativamente. Se planteó en el caso G. L. Christian \& Associates v. United States $^{103}$. En un contrato suscrito por una Army Corps of Engineers se había omitido incluir la cláusula prevista de terminación for convenience, una cláusula de rescisión del contrato ${ }^{104}$. Tal cláusula, sin embargo, debe entenderse incluida en el contrato si las regulations pueden ser leídas en el sentido de que permiten razonablemente esa interpretación ${ }^{105}$.

Es obvio que ha sido un objetivo político, consecuencia del proceso de inegración supranacional, el que ha llevado a la UE a adoptar el expuesto ordenamiento jurídico de los contratos públicos, pero ha permitido ampliar el número de los posibles contratistas y reconocer el derecho a recurrir de los licitantes no ajudicatarios del contrato, además de favorecer la concurrencia.

En resumen, la tesis expuesta supone que derechos y obligaciones de las dos partes del contrato público derivan de lo pactado. La variación, el impairment, están previstos, con las consecuencias lógicas para mantener el equilibrio que exige el objeto del contrato, equitable ajustment. De ahí la importancia de la preparación del contrato y la responsabilidad del poder contratante ${ }^{106}$, de la Administración y del government, con las correspondientes consecuencias jurídicas.

102 No es del caso advertir de la dificultad que proviene de la estructura federal y, por tanto, la existencia de cláusulas federales de diferent site, pero también de la falta de una adecuada estandarización que desarrolle enunciados genéricos y que elimine unnecessary quantity variations.

103375 U.S. 954 (1963); 382 U.S. 821 (1965).

104 Era un principio admitido desde la Primera Guerra Mundial que podían cancelarse los contratos de defensa cuando no resultaban ya necesarios, sin indemnización por los posibles beneficios posteriores a la cancelación.

105 Una aplicación de la doctrina en Dart Advantage Warehousing, Inc. v. United States (en este caso el United States Postal Service), U.S. Court of Federal Claims, 1-166 C, 2002. En él se examinan los tres modos previstos de resolver el contrato for default, convenience or upon notice.

106 La justificación de la necesidad de modificar un contrato, por ejemplo, ha de derivar de «circunstancias que un poder adjudicador diligente no hubiera podido prever» (art. 72.1.c.i de la Directiva 2014/24). 


\section{LA CONTRATACIÓN PÚBLICA COMO ESTRATEGIA POLÍTICA}

Lo expuesto ha estado dominado por una orientación jurídica, dogmática si no resultase impertinente, que no es ajena al acontecer de la Política, como ha ocurrido con otras categorías del Derecho administrativo. La contratación publica es un instrumento político de la UE así reconocido en Declaraciones oficiales. Se ha puesto de manifiesto en lo que se ha denominado "Contratación Pública Estratégica»107. La relevancia proviene de los objetivos, requeridos por apremios sociales y exigencias democráticas que no es del caso desarrollar. Desde el punto de vista de la categoría jurídica del contrato no supone novedad. Las ventas de los bienes nacionales en Francia, las desamortizaciones en España, tuvieron innegados objetivos políticos y ha sucedido y sucede en todos los países con las obras públicas ${ }^{108}$. La novedad reside en los objetivos medioambientales, sociales, innovadores; se integran con toda naturalidad en la preparación y formulación de lo que será la decisión de la Administración que con la voluntad del particular constituirá el contrato. Las políticas públicas utilizan el contrato para conseguir sus objetivos, como pueden utilizar, y así ocurre, con otras categorías, trátese de imposiciones o limitaciones unilaterales o de disposiciones necesitadas de aceptación por el particular, en lo que tradicionalmente se llamaba fomento. En la «contratación estratégica» se expone de una manera clara, colocándola nada menos que al servicio del desarrollo integral de Europa.

Desde esa perspectiva, la contratación pública rebasa el sentido que podría deducirse de un procurement ${ }^{109}$. El contrato público no es solo un medio medio jurídico para que la Administración cubra «sus» necesidades. Se lleva a cabo para satisfacer las necesidades de los ciudadanos; para la más eficiente realización del interés general. En ese sentido podría afirmarse que se ha pasado desde el contrato administrativo a la contratación pública al servicio de políticas públicas.

107 Cfr. J. J. Pernas (Dir.), Contratación Pública Estratégica, Thomson Reuters, Aranzadi, 2003, con Prólogo de J. L. MEILÁn GIL.

108 Lo reconocía Reynoso, Política administrativa del Gabinete Bravo Murillo, 1857, en el que había sido Ministro de Formento, al hacer el elogio de las obras públicas, como se hace en la actualidad, sobre todo en época de elecciones.

$109 \mathrm{El}$ direct benefit or use of the United States Government or the agency ha debido entenderse en un sentido amplio. 
